\title{
EGFR NM_005228.3:c.2236_2253del18
}

National Cancer Institute

\section{Source}

National Cancer Institute. EGFR NM 005228.3:C.2236 2253de/18. NCI Thesaurus. Code C98548.

A deletion of 18 nucleotides from the coding sequence of the EGFR gene from position 2236 through 2253. 